\title{
Studies on Bacterial Canker (Clavibacter michiganensis subsp. michiganensis) of Tomato (Solanum lycopersicum)
}

\author{
Gurvinder Singh* and Narender K. Bharat
}

\begin{abstract}
Department of Plant Pathology, Dr. Y.S. Parmar University of Horticulture and Forestry, Nauni, Solan (HP)-173 230, India

*Corresponding author
\end{abstract}

\section{A B S T R A C T}

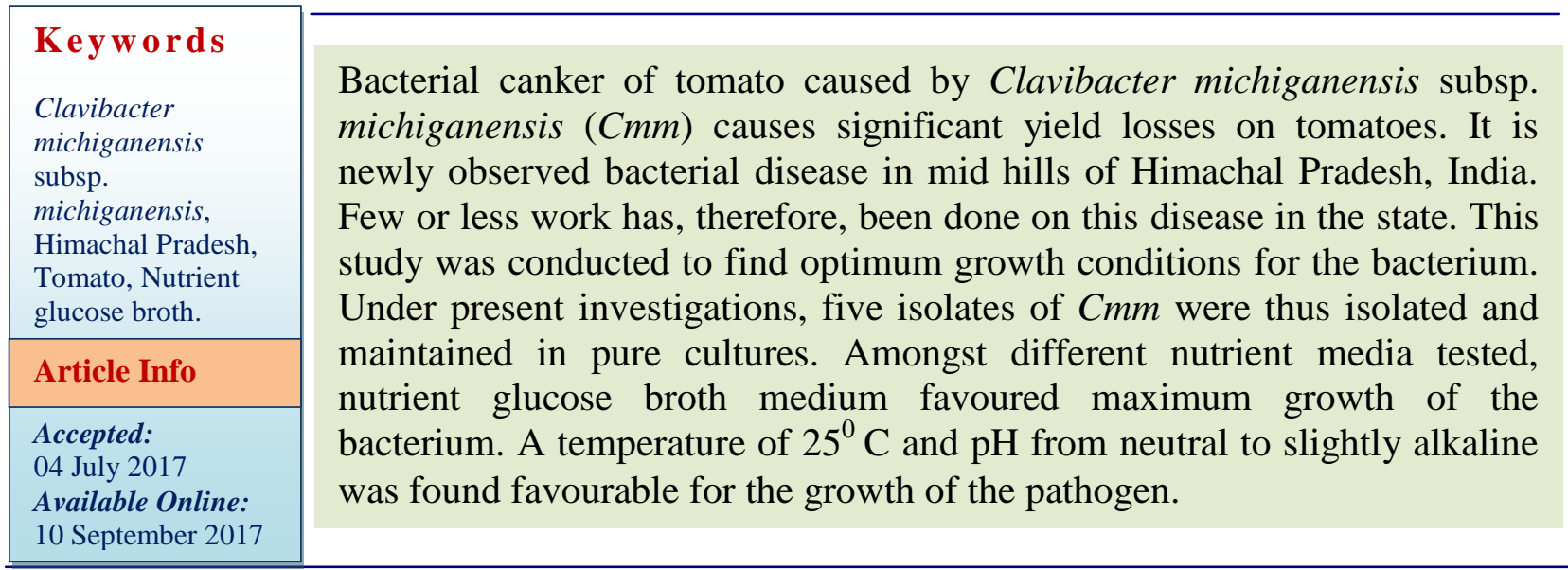

\section{Introduction}

Clavibacter michiganensis subsp. michiganensis (Smith) Davis et al., is the causal agent of bacterial canker of tomato (Solanum lycopersicum (Mill.)). The disease was first described in 1910 in Michigan, USA (Smith, 1910). The disease is widespread and destructive in the main tomato-growing areas, including the USA, Europe, Australia, New Zealand, Africa, Asia and South America. It was found to infect Lycopersicon and Capsicum species. Sweet pepper (Capsicum аппиит) as well as Solanum mammosum, $S$. douglassi, S. nigrum and Nicotiana glutinosa are also natural hosts. Furthermore a number of other solanaceous hosts are susceptible on artificial inoculation (Thyr et al., 1975, Fahy and Persely, 1983, Smith et al., 1988).

Bacterial canker is one of the most important bacterial diseases of tomato which become very destructive, if weather conditions are favourable. The disease is devastating due to the systemic movement of bacteria in the vascular tissue (Pine et al., 1955). Yield losses can be severe due to bacterial canker. Estimates of yield loss range from 10\% annual regional losses (Hibberd et al., 1992) to $84 \%$ for individual growers (Gleason et al., 1993; Strider, 1969). Yield losses attributable to bacterial canker in controlled studies range 
from 11 to 99\% (Chang et al., 1992; Emmatty and John, 1973; Ricker and Reidel, 1993). As a result of severe yield and economic losses, C. michiganensis subsp. michiganensis is a quarantine organism in the European Union and in many other countries (de Leon et al., 2008).

In India, the disease was first recorded during 1949 from Nagpur (Jain, 1951). The bacterial canker pathogen ( $C$. michiganensis subsp. michiganensis) was reported to occur in Karnataka state with an incidence up to 48 per cent (Umesha, 2006). During recent years bacterial canker has also been observed in tomato growing localities in Solan and Sirmour districts of Himachal Pradesh, India (Singh et al., 2015). It is a major disease of out-door tomato as well as under greenhouse conditions and can be very difficult to control under protected cropping.

The present investigations were conducted to isolate the bacterial canker in pure culture, to find out effective nutrient medium, temperature range and $\mathrm{pH}$ level for its isolation, growth and other studies.

\section{Materials and Methods}

The present investigations were carried out in The Department of Plant Pathology, Dr. Y.S. Parmar University of Horticulture and Forestry, Nauni, Solan (HP) during 2012-13. The materials and methods used during the studies are explained here under:

\section{Isolation, Purification and Maintenance of Pathogen Culture}

Field visits were undertaken to the tomato growing localities in Solan and Sirmour districts of Himachal Pradesh. Leaf, fruit and stem samples of tomato plants showing characteristic symptoms of Bacterial canker disease (Fig. 1) were brought to the laboratory for isolation of the pathogen. Small bits of the diseased tissues taken from affected leaves and fruits along the margin of lesions were cut with the help of sterilized scalpel. The bits were sterilized by dipping in 1 per cent mercuric chloride solution (4\% Clorax) for few seconds, washed thrice in sterile water and placed in sterile water drops on a flamed glass slide under aseptic conditions. In order to obtain bacterial ooze, incision was given in the centre of each bit with a sterile blade. Another set of these slides were also examined under the microscope for the presence of bacterial cells. A loopful of suspension was streaked on sterilized nutrient agar plates under aseptic conditions. These Petri plates were incubated at $25 \pm 2{ }^{0} \mathrm{C}$ for $48 \mathrm{~h}$ and observed for colony formation of the pathogen. Circular, creamy, and creamy to yellowish colony of the bacterium were picked from the Petri plate and Gram staining was performed. The colonies which were Gram +ve were selected. The identification of Clavibacter michiganensis subsp. michiganensis $(\mathrm{Cmm})$ was done on the basis of morphological, physiological and biochemical characters as suggested in Bergey's Manual of Determinative Bacteriology (Holt et al., 1994); Guide to Plant Pathogenic Bacteria (Bradbury, 1986) and Laboratory Guide for Identification of Plant Pathogenic Bacteria (Schaad et al., 2001). Five different isolates of $\mathrm{Cmm}$ namely, Cmm1, Cmm2, Cmm3, Cmm4 and Cmm5 were isolated from different localities in Solan and Sirmour districts. These $\mathrm{Cmm}$ isolates were purified by streak plate method and maintained on NA at $4^{0} \mathrm{C}$ for further studies.

Effect of different liquid media on the growth of different isolates of bacterial canker pathogen

Six different nutrient media namely, Nutrient broth (NB), Nutrient glucose broth (NGB), 
Nutrient yeast extract broth (NYEB), Yeast extract nutrient broth (YENB), Yeast extract sucrose peptone broth (YESPB), and Yeast extract dextrose calcium carbonate broth (YEDCCB) were used. Flasks containing 50 $\mathrm{ml}$ of different media were sterilized in autoclave at $15 \mathrm{lbs}$. $/ \mathrm{inch}^{2}$ for 20 minutes. For each broth medium five different replications were taken and were inoculated with the bacterium. One loopful of the bacterial culture was inoculated in each of the flasks replication wise and incubated at the most effective temperature for the growth of bacterium in BOD incubator cum orbital shaker at $140 \mathrm{rpm}$ for 48 hours. After 2 days of incubation the bacterial growth was seen in the media and the optical density (OD) of the culture was calculated by using Spectrophotometer at $540 \mathrm{~nm}$.

\section{Effect of different temperature regimes on the growth of different isolates of bacterial canker pathogen}

To study the effect of different temperature regimes viz., $10,15,20,25,30,35$ and $40^{\circ} \mathrm{C}$ on growth of the bacterium, $150 \mathrm{ml}$ 'Erlenmeyer' flasks, each containing $50 \mathrm{ml}$ of sterilized NB ( $\mathrm{pH}$ 7.0) were autoclaved. After that inoculated with a loopful of 48 hours old bacterial culture inside a laminar air flow chamber and incubated at different temperature regimes for 48 hours along with uninoculated flasks containing nutrient broth and supplemented with $1.5 \mathrm{ml}$ of sterile distilled water to serve as check. Each treatment was replicated thrice. The OD value of each replication was observed by using Spectrophotometer at $540 \mathrm{~nm}$.

Effect of different pH Levels on the growth of different isolates of bacterial canker pathogen

The effect of different $\mathrm{pH}$ levels viz., 4, 5, 6, 7 and 8 was observed on growth of the bacterium under laboratory condition. $150 \mathrm{ml}$ 'Erlenmeyer flasks, each containing $50 \mathrm{ml}$ of NB were subjected to adjustment of desired $\mathrm{pH}$ levels of the medium by adding $\mathrm{N} / 10 \mathrm{HCl}$ or $\mathrm{N} / 10 \mathrm{NaOH}$. The desired $\mathrm{pH}$ levels in acidic and alkaline ranges, respectively and recorded with the help of digital $\mathrm{pH}$ meter. After sterilization at $15 \mathrm{lbs}$. $/ \mathrm{Inc}^{2}$ pressure for 20 minutes, each of the flasks were inoculated with a loopful of 48 hours old bacterial culture and incubated at $25^{\circ} \mathrm{C}$ along with the uninoculated flasks supplemented with equal volume of sterile distilled water in place of inoculum, to serve as check. After 2 days of incubation the growth of bacterial culture appeared in broth. The OD value of each replication was calculated by using Spectrophotometer at $540 \mathrm{~nm}$.

\section{Results and Discussion}

Effect of different liquid media on the growth of different isolates of bacterial canker pathogen

From the data (Table 1) it is evident that highest growth in terms of optical density (1.86) was recorded in nutrient glucose broth medium followed by Yeast extract dextrose calcium carbonate broth medium (1.85) and yeast extract sucrose peptone broth medium (1.82). Lowest optical density was recorded in nutrient broth medium. Amongst various isolates, $\mathrm{Cmm} 3$ and $\mathrm{Cmm} 4$ exhibited maximum OD value of 1.90 and 1.92 in yeast extract dextrose calcium carbonate broth medium. The growth of bacterial canker pathogen isolates was better in nutrient glucose broth medium followed by yeast extract dextrose calcium carbonate broth medium. Nutrient glucose broth medium has been found better under present investigations. Smith et al., (1988) also reported that optimal growth is achieved in nutrient glucose agar where colonies are 1 $\mathrm{mm}$ in diameter after 3-5days and 2-3 mm 
after 7-8 days in culture. Various workers have evaluated different culture media for isolation of bacterial canker pathogen and have used nutrient glucose yeast extract medium (NGYEM) for storing various isolates of the pathogen (Ftayeh et al., 2011). However, they modified the medium later on for better growth of the bacterium.

Fig.1 Characteristic symptoms of Bacterial canker disease of tomato on a) leaves, b) fruit, c) stem, and d) dead tomato plants due to bacterial canker

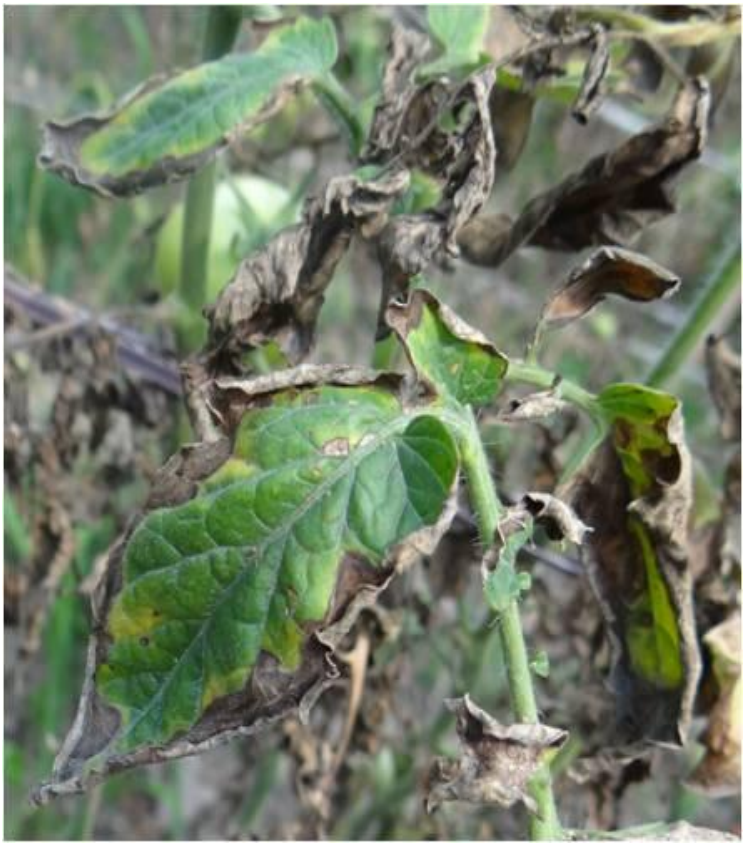

a.

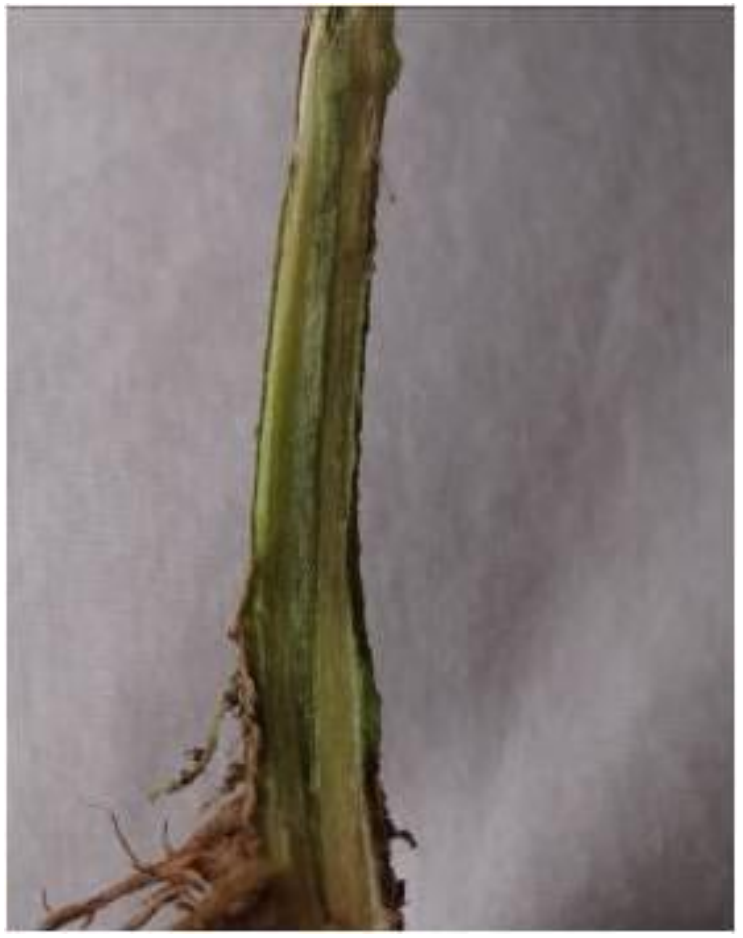

c.

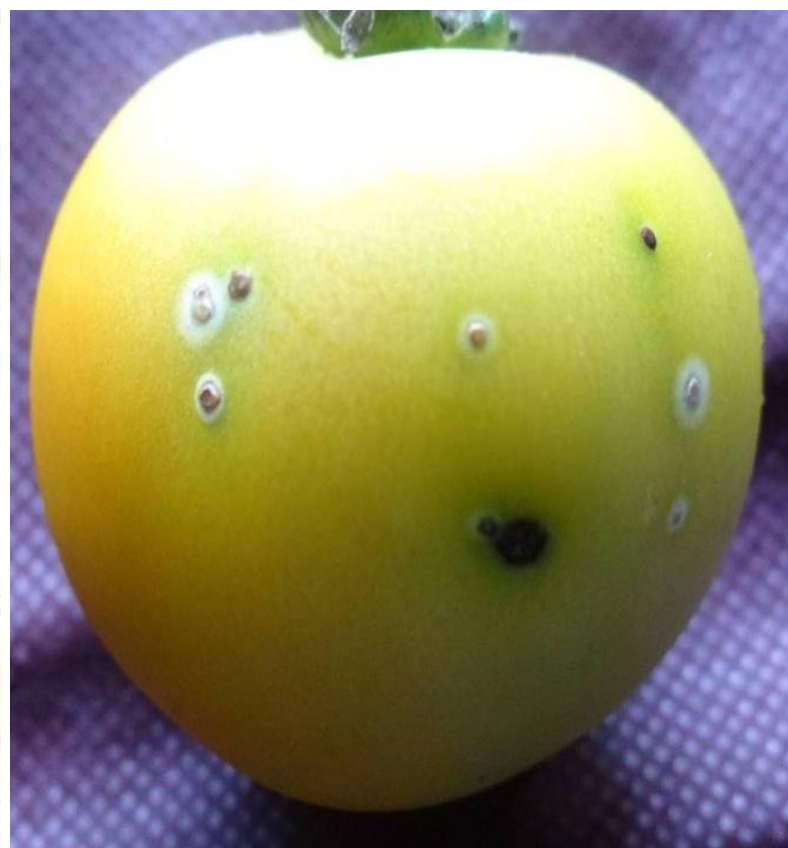

b.

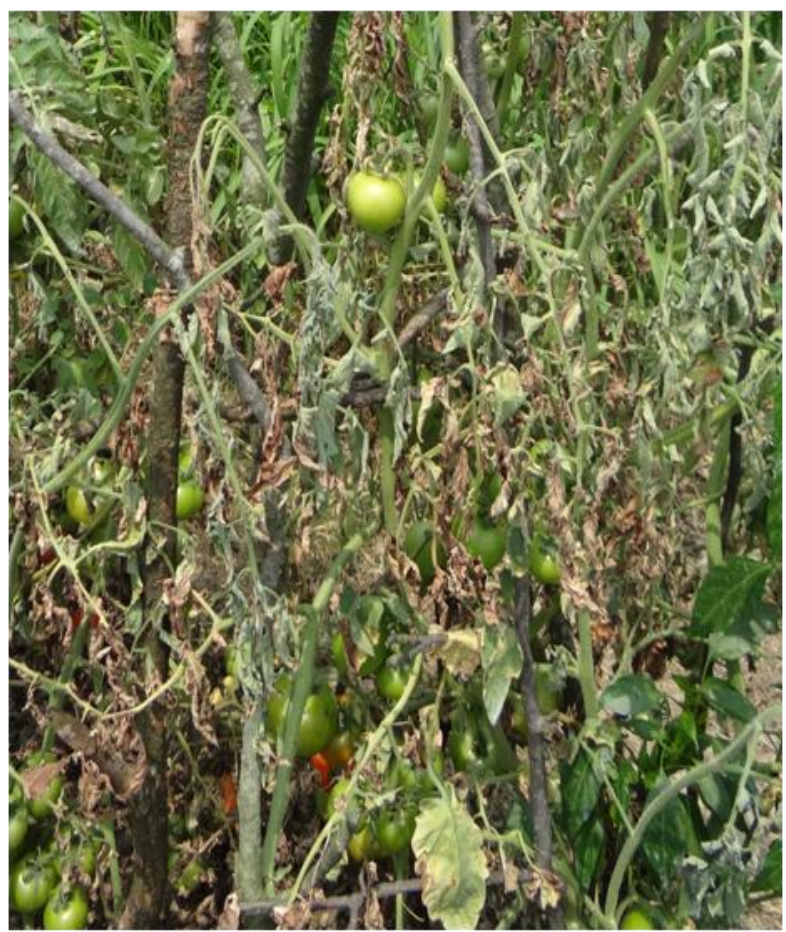

d. 
Table.1 Effect of different liquid media on growth (optical density) of various isolates of bacterial canker pathogen of tomato

\begin{tabular}{|l|l|l|l|l|l|l|}
\hline \multirow{2}{*}{ Nutrient medium } & \multicolumn{9}{|l|}{ Optical density of isolates of bacterial pathogen } & \multirow{2}{*}{ Mean } \\
\cline { 2 - 7 } & $\mathbf{C m m 1}$ & $\mathbf{C m m 2}$ & $\mathbf{C m m 3}$ & $\mathbf{C m m 4}$ & $\mathbf{C m m 5}$ & \\
\hline Nutrient broth medium & 1.71 & 1.73 & 1.73 & 1.76 & 1.70 & 1.73 \\
\hline Yeast extract nutrient broth medium & 1.75 & 1.79 & 1.88 & 1.73 & 1.69 & 1.77 \\
\hline Nutrient glucose broth medium & 1.85 & 1.82 & 1.87 & 1.89 & 1.86 & 1.86 \\
\hline Nutrient yeast extract broth medium & 1.79 & 1.80 & 1.82 & 1.75 & 1.70 & 1.77 \\
\hline Yeast extract sucrose peptone broth medium & 1.87 & 1.88 & 1.80 & 1.85 & 1.69 & 1.82 \\
\hline Yeast extract dextrose calcium carbonate broth medium & 1.85 & 1.80 & 1.90 & 1.92 & 1.79 & 1.85 \\
\hline Mean & 1.80 & 1.81 & 1.83 & 1.82 & 1.74 & \\
\hline
\end{tabular}

C.D. (0.05); Isolates $=0.01 ;$ Media $=0.01 ;$ Isolate $\times$ Media $=0.02$

Table.2 Effect of different temperature regimes on the growth (optical density) of various isolates of bacterial canker pathogen of tomato

\begin{tabular}{|l|l|l|l|l|l|l|}
\hline \multirow{2}{*}{$\begin{array}{l}\text { Temperature } \\
(\mathbf{0} \mathbf{C})\end{array}$} & \multicolumn{9}{|l|}{ Optical density of isolates of bacterial pathogen } & \multirow{2}{*}{ Mean } \\
\cline { 2 - 6 } & $\mathbf{C m m 1}$ & $\mathbf{C m m 2}$ & $\mathbf{C m m 3}$ & $\mathbf{C m m 4}$ & $\mathbf{C m m 5}$ & \\
\hline $\mathbf{1 0}$ & 0.52 & 0.48 & 0.96 & 0.99 & 0.42 & 0.67 \\
\hline $\mathbf{1 5}$ & 1.18 & 1.19 & 1.10 & 1.03 & 0.72 & 1.04 \\
\hline $\mathbf{2 0}$ & 1.25 & 1.26 & 1.29 & 1.23 & 1.24 & 1.25 \\
\hline $\mathbf{2 5}$ & 1.39 & 1.44 & 1.59 & 1.47 & 1.46 & 1.47 \\
\hline $\mathbf{3 0}$ & 1.24 & 1.40 & 1.52 & 1.39 & 1.32 & 1.37 \\
\hline $\mathbf{3 5}$ & 0.79 & 1.21 & 0.88 & 0.92 & 0.94 & 0.95 \\
\hline $\mathbf{4 0}$ & 0.26 & 0.87 & 0.53 & 0.63 & 0.66 & 0.59 \\
\hline Mean Isolates & 0.95 & 1.12 & 1.12 & 1.09 & 0.97 & \\
\hline
\end{tabular}

C.D. (0.05); Isolates $=0.01 ;$ Temperature $=0.01 ;$ Isolate $\times$ Temperature $=0.03$

Table.3 Effect of different $\mathrm{pH}$ levels on the growth (optical density) of various isolates of bacterial canker pathogen of tomato

\begin{tabular}{|l|l|l|l|l|l|l|}
\hline \multirow{2}{*}{ pH Level } & \multicolumn{9}{|l|}{ Optical density of isolates of bacterial pathogen } & \multirow{2}{*}{ Mean } \\
\cline { 2 - 6 } & $\mathbf{C} \boldsymbol{m} \mathbf{1}$ & $\boldsymbol{C m m 2}$ & $\mathbf{C m m 3}$ & $\boldsymbol{C} \mathbf{m} \mathbf{4}$ & $\mathbf{C m m 5}$ & \\
\hline $\mathbf{4}$ & 0.07 & 0.10 & 0.07 & 0.07 & 0.05 & 0.07 \\
\hline $\mathbf{5}$ & 0.90 & 0.93 & 0.92 & 1.07 & 1.19 & 1.00 \\
\hline $\mathbf{6}$ & 1.30 & 1.28 & 1.26 & 1.30 & 1.32 & 1.29 \\
\hline $\mathbf{7}$ & 1.30 & 1.36 & 1.44 & 1.30 & 1.39 & 1.36 \\
\hline $\mathbf{8}$ & 1.28 & 1.43 & 1.50 & 1.33 & 1.29 & 1.36 \\
\hline Mean & 0.97 & 1.02 & 1.04 & 1.01 & 1.05 & \\
\hline
\end{tabular}

C.D. (0.05); Isolates $=0.01 ; \mathrm{pH}$ level $=0.01$; Isolate $\times \mathrm{pH}$ level $=0.02$

Effect of different temperature regimes on the growth of different isolates of bacterial canker pathogen

The effect of different temperature ranges on the growth w.r.t. the optical density of the culture of bacterial canker pathogen was observed significant (Table 2). Amongst different temperature regimes tested, maximum growth of bacterial isolates was observed at $25^{\circ} \mathrm{C}$. The bacterial growth on the temperatures below and above $25^{\circ} \mathrm{C}$ declined which suggested that $25^{\circ} \mathrm{C}$ is the optimum temperature for the growth of bacterial canker pathogen. Eichenlaub et al., (2006) observed that Clavibacter michiganensis subsp. 
michiganensis grows optimally at $25^{\circ} \mathrm{C}$. The optimum temperature range for bacterial canker of tomato has also been observed between $25-30^{\circ} \mathrm{C}$ (Anon., 2013; Sen et al., 2015).

\section{Effect of different pH levels on the growth of different isolates of bacterial canker pathogen}

It is evident from the data in table 3 that the bacterial canker pathogen grew to a variable extent at all the $\mathrm{pH}$ levels tested. Amongst the various $\mathrm{pH}$ levels, maximum growth w.r.t. optical density was recorded at $\mathrm{pH} 8.0$ followed by $\mathrm{pH}$ 7.0. The growth at $\mathrm{pH} 6.0$ and 5.0 were next best in the order and did not differ significantly with each other. However, the growth w.r.t. OD value at $\mathrm{pH} 4.0$ was minimum differing significantly from rest of the $\mathrm{pH}$ levels. Therefore, neutral to slightly alkaline $\mathrm{pH}$ proved better for growth of bacterial canker pathogen. Huang and Tu (1999) have observed neutral to slightly high $\mathrm{pH}$ to be better for growth of bacterial canker pathogen of tomato. Eichenlaub et al., (2006) observed that optimum $\mathrm{pH}$ for growth of this bacterium is between 7 and 8 . Hence, the results of present investigation corroborate the findings of such earlier studies.

It can be concluded that the Bacterial canker of tomato (Clavibacter michiganensis subsp. michiganensis) pathogen grew better on nutrient glucose broth medium at temperature range of $25-30^{\circ} \mathrm{C}$ with a $\mathrm{pH}$ level between neutral to slightly alkaline.

\section{References}

Anonymous, 2011. Handbook of Indian Horticulture Database, National Horticulture Board, Gurgaon (Ha.) India.

Anonymous, 2013. Clavibacter michiganensis subsp. michiganensis. Quarantine Pests for Europe, 2nd ed., CAB International, Wallingford (GB) pp 980-985.

Bradbury, J.F., 1986. Guide To Plant Pathogenic Bacteria. CAB International Mycological Institute, Slough, UK.

Chang, R.J., S. M. Ries, and Pataky, J. K. 1992. Reductions in yield of processing tomatoes and incidence of bacterial canker. Plant Disease, 76:805-809.

De Leon, L., F. Siverio, M. M. Lopez, and Rodriguez, A. 2008. Comparative efficiency of chemical compounds for in vitro and in vivo activity against Clavibacter michiganensis subsp. michiganensis, the causal agent of tomato bacterial canker. Crop Protection, 27:1277-1283.

Eichenlaub, R., K. H. Gartemann, and Burger, A. 2006. Clavibacter michiganensis, a group of gram-positive phytopathogenic bacteria. Pages 385- 421 in: PlantAssociated Bacteria. Springer, the Netherlands.

Emmatty, D. A., and John, C. A. 1973. Comparison of yield loss to bacterial canker of tomato in a resistant and a susceptible variety. Plant Disease Reporter, 57:787-788.

Fahy, P.C., and Persley, G.J. Eds. 1983. Plant Bacterial Diseases. A Diagnostic Guide. Academic press. Sydney, New York. pp. 1 -393.

Ftayeh, R.M., A. von Tiedemann, and Rudolph, K. 2011. A new selective medium for isolation of Clavibacter michiganensis subsp. michiganensis from tomato plants and seed. Phytopathology, 101(11): 1355-1364.

Gleason, M. L., R. D. Gitaitis, and Ricker, M.

D. 1993. Recent progress in understanding in controlling bacterial canker of tomato in Eastern North America. Plant Disease, 77: 1069-1076.

Gomez, K.A., and Gomez, A.A. 1986. Statistical Procedure of Agricultural Research. $2^{\text {nd }}$ ed. John willey and Sons, 
New York, U.K., 680 p.

Gupta, S.K., and Thind, T.S. 2006. Disease Problems in Vegetable Production. Scientific Publishers (India), Jodhpur, $576 \mathrm{p}$.

Hausbeck, M.K., M.C. Medina, R. Podolsky, and Fulbright, D.W. 2000. Effect of bactericides on population sizes and spread of Clavibacter michiganensis subsp. michiganensis on tomatoes in the greenhouse and on disease development and crop yield in the field. Phytopathology, 90: 38-44.

Hibberd, A. M., J. B. Heaton, G. P. Finlay, and Dullahide, S. R. 1992. A greenhouse method for selecting tomato seedlings resistant to bacterial canker. Plant Disease, 76:1004-1007

Holt, J.G., N.R. Krieg, P.H.A. Sneath, J.T. Staley, and Williams, S.T. 1994. Bergey's Manual of Determinative Bacteriology. Williams and Wilkins, Baltimore.

Huang, R., and Tu, J.C. 1999. Effect of the NFT nutrient solution $\mathrm{pH}$ on root transmission of tomato bacterial canker (Clavibacter michiganensis subsp. michiganensis). Acta Horticulturae 481: 569-572.

Jain, A. C., 1951. A bacterial disease (canker) of tomatoes new to India. Science Culture 17: 46-47.

Pine T. S., R. G. Grogan, and Hewitt, W. B. 1955. Pathological anatomy of bacterial canker of young tomato plants. Phytopathology, 45:267-271.

Ricker, M. D., and Reidel, R. M. 1993. Effect of secondary spread of Clavibacter michiganensissubsp. michiganensis on yield of Northern processing tomatoes. Plant Disease, 77:364-366.

Schaad, N.W., J.B. Jones, and Chun, W. 2001. Laboratory Guide for Identification of Plant Pathogenic Bacteria, 3rd ed. American Phytopathological Society Press, 373 p.

Sen, Y., J.van der Wolf, R.G.F. Visser, and van Heusden, S. 2015. Bacterial canker of tomato: Current knowledge of detection, management, resistance and interactions. Plant Disease, 99(1): 4-13.

Singh, G., N.K. Bharat, and Sharma, M. 2015. Occurrence of bacterial canker of tomato in Himachal Pradesh, India: Identification and molecular characterization of the pathogen. The Bioscan, 10(4): 1753-1757.

Smith, E. F., 1910. A new tomato disease of economic importance. Science, 31:794796.

Smith, I. M., J. Dunez, D. H. Philips, R. A. Lelliott, and Archer, S. A. 1988. European Handbook of Plant diseases. Blackwell Scientific Publications. UK, pp. 1-198.

Strider, D. L., 1969. Bacterial canker of tomato, a literature review and bibliography. N. C. Agric. Exp. Stn. Tech. Bull. 193.

Thyr, B. D., M. J. Samuel, and Brown, P. G. (1975): Tomato bacterial canker: control by seed treatment. Plant Disease Reporter, 59: 595-598.

Umesha, S., 2006. Occurrence of bacterial canker in tomato fields of Karnataka and effect of biological seed treatment on disease incidence. Crop Protection, 25: $375-381$.

\section{How to cite this article:}

Gurvinder Singh and Narender K. Bharat. 2017. Studies on Bacterial Canker (Clavibacter michiganensis sub sp. michiganensis) of Tomato (Solanum lycopersicum). Int.J.Curr.Microbiol.App.Sci. 6(9): 317-323. doi: https://doi.org/10.20546/ijcmas.2017.609.040 